\title{
PEMBUKTIAN TERBALIK SEBAGAI KEBIJAKAN KRIMINAL DALAM PENANGANAN TINDAK PIDANA KORUPSI
}

\author{
Oleh : Kukun Abdul Syakur Munawar, S.H., M.H.")
}

\begin{abstract}
Reversed evidence is necessary in the process of handling corruption cases more easily in ensnling the perpetrators of corruption as long as the suspect or suspect can not prove that his wealth is obtained from a legitimate way, in addition to the reverse proof in addition to easier proof is also more effective power to prevent it from the present proof we now embrace, and the surplus proof of lies in the ability of the accused to prove that his property is not the product of corruption. Constraints in the implementation of reverse verification policy is the reverse proof that is too much politicized so that the apparatus involved both the investigator and the public prosecutor do not apply the indictment properly. Thus, it is necessary to amend the law no. 20 Year 2001 on the Criminal Act of Corruption. in addition to the majority of property owned by the perpetrators of corruption rather than on behalf of the perpetrators of corruption or in other words the perpetrators of corruption is doing money laundering in order to disguise property from the criminal corruption, so it will be difficult if there should be an upside proof.
\end{abstract}

Keywords: Corruption, Reversed Proof

\section{ABSTRAK}

Pembuktian terbalik sangat diperlukan dalam proses penanganan kasus tindak pidana korupsi dan lebih dipermudah dalam menjerat para pelaku tindak pidana korupsi sepanjang terduga atau tersangka tidak dapat membuktikan bahwa harta kekayaannya didapat dari jalan yang sah, disamping itu dengan pembuktian terbalik selain akan lebih mudah pembuktiannya juga lebih efektif daya cegahnya daripada pembuktian yang sekarang kita anut sekarang, dan kelebihan pembuktian terbalik terletak pada kemampuan terdakwa untuk membuktikan bahwa kekayaan yang dimilikinya bukan merupakan hasil dari tindak pidana korupsi. Kendala kendala dalam penerapan kebijakan pembuktian terbalik tersebut disinyalir karena terlalu banyak dipolitisir sehingga aparat yang terlibat baik itu penyidik maupun penuntut umum tidak menerapkan dakwaan sebagaimana mestinya. Sehingga, perlu diadakan perubahan terhadap Undang-undang Nomor 20 Tahun 2001 tentang Tindak Pidana Korupsi. disamping kebanyakan harta kekayaan yang dimiliki oleh pelaku tindak pidana korupsi bukan atas nama dari pelaku korupsi tersebut atau dengan kata lain para pelaku korupsi tersebut melakukan pencucian uang guna menyamarkan harta kekayaan dari hasil tindak pidana korupsi, sehingga akan sulit jika harus diadakan pembuktian terbalik.

Kata Kunci : Korupsi , Pembuktian Terbalik

\footnotetext{
*) Tenaga Pengajar Fakultas Hukum Universitas Galuh
} 


\section{PENDAHULUAN}

\section{A. Latar Belakang Masalah}

Usaha pemberantasan korupsi jelas tidak mudah, kesulitan itu terlihat semakin rumit karena korupsi kelihatan benar-benar menjadi budaya pada berbagai level masyarakat (Hibnu Nugroho; 2013). Pada dasarnya, secara normatif bahwa tindak pidana korupsi merupakan kejahatan yang luar biasa (extra ordinary crimes). Apabila dikaji dari pandangan doktrin (Romli Atmasasmita; 2002 : 25) menekankan bahwa :

Dengan memperhatikan perkembangan tindak pidana korupsi baik dari sisi kualitas maupun kuantitas, dan setelah mengkajinya secara mendalam, tidaklah berlebihan jika dikatakan bahwa korupsi di Indonesia bukan kejahatan biasa (Ordinary Crimes), melainkan sudah merupakan kejahatan yang sangat luar biasa (extra ordinary crimes) . selanjutnya jika dikaji dari sisi akibat atau dampak negatif yang sangat merusak tatanan kehidupan bangsa Indonesia sejak pemerintahan orde baru sampai saat ini, jelas bahwa perbuatan korupsi merupakan perampasan hak ekonomi dan hak sosial rakyat Indonesia.

Konsekuensi logis bahwa tindak pidana korupsi merupakan extra ordinary crimes, diperlukan penanggulangan dari aspek yuridis yang luar biasa (extra ordinary enforcement) dan perangkat hukum yang luar biasa pula (extra ordinary measures). dari dimensi inilah salah satu langkah komprehensif yang dapat dilakukan dalam sistem peradilan pidana Indonesia adalah melalui sistem pembuktian (Lilik Mulyadi; 2007 : 252-253).

Dalam pemberantasan Tindak Pidana Korupsi dengan menggunakan ketentuan-ketentuan yang ada dalam KUHP dinilai kurang memadai karena itu diterapkan dalam keadaan darurat perang melalui Peraturan Penguasa Perang Pusat AD (P4AD) Prt/ PERPU/031/1958 tentang Pengusutan, Penuntutan, dan Pemeriksaan Perbuatan Korupsi, kemudian pada tahun 1960 dibuatlah UU No. 24 Tahun 1960 tentang Pengusutan, Penuntutan, dan Pemeriksaan Tindak Pidana Korupsi. Karena dirasa kurang memadai, yang kemudian Persoalan muncul sehubungan dengan tuntutan untuk menerapkan asas pembuktian terbalik yang harus dilakukan oleh terdakwa, maka pada tahun 1971 dibentuk UU No. 3 Tahun 1971 tentang Pemberantasan Tindak Pidana Korupsi, dimana sejak dalam pembahasannya UU ini sebenarnya berkeinginan untuk menggunakan 
sistem pembuktian terbalik namun selalu terhalang dengan alasan pembuktian terbalik bertentangan dengan asas praduga tidak bersalah, namun, dengan memperhatikan prinsip lex specialis derogat legi generalis akhirnya pada tahun 1999 diundangkan UU No. 31 Tahun 1999 tentang Pemberantasan Tindak Pidana Korupsi, yang menganut sistem pembuktian terbalik terbatas. ini dijamin dalam Pasal 37 yang memungkinkan diterapkannya pembuktian terbalik yang terbatas terhadap tertentu dan mengenai perampasan harta hasil korupsi, namun Pasal 37 ini tidak menyatakan secara tegas perlunya pembalikan beban pembuktian.

Oleh karena tidak diatur secara khusus, maka penerapannya dapat menimbulkan persepsi dan interpretasi bagi para penegak hukum, dan kemudian dipertegas lagi dengan di undangkannya UU No. 20 Tahun 2001 tentang Pemberantasan Tindak Pidana Korupsi, yakni berupa Sistem Pembalikan Beban Pembuktian Terbatas dan Berimbang. Yang mengatur pembuktian terbalik secara lebih jelas yaitu pada Pasal $12 \mathrm{~B}, 12 \mathrm{C}, 37 \mathrm{~A}$, $38 \mathrm{~A}$, dan 38B.

Walaupun rancangan perundang-undangan mengenai pembuktian terbalik masih terus digodok oleh pemerintah karena masih mengundang pro dan kontra, akan tetapi dengan terealisasinya penggunaan asas pembuktian terbalik telah dilakukan yaitu pada UU Nomor : 31 Tahun 1999 jo UU No.20 Tahun 2001 tentang Pemberantasan tindak pidana korupsi yang menggunakan asas pembuktian terbalik.

Berdasarkan uraian diatas penulis tertarik untuk melakukan penelitian yang berjudul "Pembuktian Terbalik Sebagai Kebijakan Kriminal Dalam Penanganan Tindak Pidana Korupsi (Studi di Kejaksaan Negeri Ciamis Dan Kejaksaan Negeri Kota Banjar)"

\section{B. Perumusan Masalah}

Berdasarkan latar belakang yang telah diuraikan di atas, yang menjadi fokus permasalahan dalam penulisan ini adalah mengapa dibutuhkan kebijakan kriminal dalam hal pembuktian terbalik dari pelaku tindak pidana korupsi dengan menggunakan rambu-rambu undang-undang dan alat bukti lain yang sah menurut undang-undang, untuk memudahkan 
penyusunan karya ilmiah ini maka diambil rumusan masalah sebagai berikut :

1. Mengapa pembuktian terbalik belum diterapkan dalam tindak pidana korupsi ?

2. Kendala-kendala apa saja yang dihadapi dalam pembuktian terbalik tindak pidana korupsi di Kejaksaan Negeri Ciamis dan Kejaksaan Negeri Kota Banjar?

\section{Tujuan Penelitian}

Sesuai dengan rumusan masalah yang telah diuraikan di atas penelitian ini memiliki tujuan diantaranya sebagai berikut ;

1. Untuk menganalisis dan mengetahui penerapan pembuktian terbalik dalam penanganan pengungkapan tindak pidana korupsi yang dilakukan oleh Kejaksaan Negeri Ciamis dan Kejaksaan Negeri Kota Banjar

2. Untuk mengetahui dan menganalisis kendala atau hambatan-hambatan yang dihadapi oleh Jaksa Penuntut Umum dalam menerapkan pembuktian terbalik dalam kasus tindak pidana korupsi.

\section{Tinjauan Pustaka}

Secara umum, istilah "kebijakan" atau "policy" digunakan untuk menunjuk perilaku seorang aktor, (misalnya seorang pejabat, suatu kelompok, maupun suatu lembaga pemerintah) atau sejumlah aktor dalam suatu bidang tertentu. Pengertian kebijakan seperti ini dapat digunakan relatif memadai untuk keperluan pembicaraan-pembicaraan biasa, namun menjadi kurang memadai untuk pembicaraan-pembicaraan yang lebih bersifat ilmiah dan sistematis menyangkut analisis kebijakan publik Pada dasarnya terdapat banyak batasan atau definisi mengenai apa yang dimaksud dengan Public Policy dalam literatur-literatur ilmu politik masingmasing memberikan definisi yang berbeda-beda, perbedaan ini timbul karena masing-masing ahli memiliki latar belakang yang berbeda-beda. (Budi Winarno, 2012 : 19).

Robert Eyestone sebagaimana dikutip oleh Budi Winarno mendefinisikan Kebijakan Publik "secara luas" didefinisikan sebagai hubungan suatu unit pemerintah dengan lingkungannya (Budi Winarno, 
2002 : 15). Menurut Budi Winarno Konsep yang ditawarkan oleh Robert Eyestone ini mengandung pengertian yang sangat luas dan kurang pasti karena apa yang dimaksud dengan kebijakan publik dapat mencakup banyak hal (Budi Winarno, 2012 : 15).

Anderson dalam Budi Winarno, mendefinisikan kebijakan publik merupakan arah tindakan yang mempunyai maksud yang ditetapkan oleh seorang aktor atau sejumlah aktor dalam mengatasi suatu masalah atau suatu persoalan (Budi Winarno, 2012 : 16). Konsep Kebijakan ini menurut Budi Winarno dianggap tepat karena memusatkan perhatian pada apa yang sebenarnya dilakukan dan bukan apa yang diusulkan atau dimaksudkan (Budi Winarno, 2012 : 16).

Thomas $\mathrm{R}$ Dye sebagaimana dikutip oleh Riant Nugroho mendefinisikan Kebijakan Publik sebagai segala sesuatu yang dikerjakan pemerintah, mengapa mereka melakukan, dan hasil yang membuat sebuah kehidupan bersama tampil beda (public policy is "Whatever government choose to do or not do, Public Policy is what Government do, Why they do it, and what difference it make") (Riant Nugroho; 2014 :126).

Ada tiga hal pokok yang perlu diperhatikan dalam analisis kebijakan yakni ; pertama fokus utamanya adalah mengenai penjelasan kebijakan bukan mengenai anjuran kebijakan yang "pantas", kedua sebab-sebab dan konsekuensi-konsekuensi dari kebijakan-kebijakan pubik diseidiki dengan teliti dan dengan menggunakan metodologi ilmiah, ketiga analisis dilakukan dalam rangka mengembangkan teori umum yang dapat diandalkan tentang kebijakan-kebijakan publik dan pembentukannya, sehingga dapat diterapkan terhadap lembaga-lembaga dan bidang-bidang kebijakan yang berbeda , dengan demikian analisis kebijakan dapat bersifat ilmiah dan relevan bagi masalah-masalah politik sosial sekarang (Budi Winarno; 2012 : 27).

Penanggulangan dan pencegahan terhadap kejahatan merupakan cara masyarakat bereaksi terhadap fenomena kejahatan, tiap-tiap masyarakat akan bereaksi terhadap kejahatan sesuai dengan tingkat kebudayaan yang telah dicapai oleh masyarakat yang bersangkutan. Reaksi terhadap kejahatan dapat dibagi menjadi tiga kelompok berikut (M Zaidan Ali; 2016 : 02-103) :

1. Respon yang bersifat non formal yang dilakukan oleh masyarakat sendiri 
dari cara-cara lunak hingga cara-cara yang keras seperti main hakim sendiri.

2. Respon yang bersifat informal dilakukan dalam bentuk teguran atau peringatan terhadap orang-orang yang diduga melakukan pelanggaran hukum.

3. Respon yang bersifat formal, metode yang digunakan untuk melawan kejahatan dilakukan secara formal melalui sistem peradilan.

Respon formal merupakan reaksi negara untu menaggulangi kejahatan. respon formal dimulai dari penyelidikan, diteruskan dengan penyidikan, penuntutan, pemeriksaan di sidang pengadilan, dan ditetapkan hukumnya oleh hakim. Penegakan hukum ini ditujukan untuk merealisasikan atau mencapai atau mewujudkan nilai-nilai hukum agar menjadi kenyataan, mewujudkan nilai hukum yakni keadilan (M Zaidan Ali , 2016 : 109).

Apabila keadilan diwujudkan dalam pengertian semua pihak diperlukan dengan adil setelah melalui proses hukum yang fair, maka akan terwujud substantive justice atau keadilan substantif. sebaliknya apabila penegakan hukum hanya dijalankan agar terwujudnya kepastian hukum maka hanya akan terwujud procedural justice, keadilan prosedural ini merupakan proses hukum yang dilakukan untuk memenuhi ketentuan hukum postif belaka, tindakan demikian terkadang dapat mengenyampingkan keadilan substantif, hukum telah dijalankan tapi keadilan diabaikan (M. Zaidan Ali , 2016 : 109).

Pada hakikatnya hukum pidana dan kegunaannya bermaksud agar setiap anggota masyarakat dapat dilindungi untuk mencapai jalan hidup yang sejahtera lahir dan batin, sehubungan dengan perlindungan hukum pidana bagi masyarakat dan anggotanya itu perlu diingatkan tentang perkembangan pandangan hukum yang baru karena sejak lama dipikirkan bahwa fungsi primer hukum pidana itu hendaknya mengingat sifat negatifnya sanksi pidana agar baru diterapkan apabila upaya lain sudah tidak memadai lagi (H. Moh. Hatta, 2016 : 51-52).

\section{Kebijakan Hukum Pidana Dan Kebijakan Kriminal}

Istilah kebijakan hukum pidana lazim juga disebut dengan pembaharuan hukum pidana, Barda Nawawi Arief sebagaimana dikutip oleh 
M Ali Zaidan mengemukakan, istilah pembaharuan hukum pidana disebut juga dengan politik hukum pidana atau kebijakan formulatif yang diartikan sebagai upaya untuk melakukan reorientasi dan reformasi hukum pidana yang sesuai dengan nilai-nilai sosiopolitik, sosiofilosofis, serta sosiokultutal masyarakat Indonesia yang melandasi kebijakan sosial, kebijakan kriminal, dan kebijakan penegakan hukum di Indonesia (M. Ali Zaidan, 2016 : 124).

Kebijakan hukum pidana, politik hukum pidana atau pembaharuan hukum pidana, begitu juga dengan kebijakan formulatif dan kebijakan perundang-undangan, merupakan istilah sinonim yang merupakan salah satu permasalahan yang dihadapi oleh bangsa Indonesia saat ini, hal ini disebabkan karena sebagian besar hukum di Indonesia merupakan penerusan dari sistem hukum sebelumnya dengan alasan untuk mencegah kekosongan hukum, ketentan hukum penjajah tetap diberlakukan sampai diadakannya hukum baru sesuai dengan sistem ketatanegaraan maupun falsafah hidup bangsa Indonesia, pada sisi lain pembaharuan hukum pidana terus dilakukan dengan memperhatikan perkembangan dunia disamping memelihara hukum yang hidup dalam masyarakat sebagai cara pandang bangsa Indonesia dalam berhukum (M. Ali Zaidan, 2016 : 124-125).

Dalam rangka kebijakan hukum pidana hendaklah diperhatikan jangan sampai terjadi tumpang tindih kewenangan antar lembaga negara, subsistem penyelidikan, penyidikan, penuntutan, peradilan, dan eksekusi hukuman harus ditegaskan batas-batasnya guna mencegah pelampauan batas kewenangan atau penyalahgunaan wewenang. Kebijakan hukum pidana pada hakikatnya merupakan bidang politik hukum yang menurut Soedarto sebagaimana dikutip oleh M Ali Zaidan diartikan sebagai kebijakan dari negara melalui badan-badan negara yang berwenang untuk menetapkan peraturan yang dikehendaki yang diperkirakan akan digunakan untuk mengekspresikan apa yang terkadung dalam masyarakat dan untuk mencapai apa yang di cita-citakan (M. Ali Zaidan; 2016 : 144-145).

Upaya penanggulangan dan pencegahan tindak pidana korupsi dapat dilakukan dengan berbagai macam cara, selain dengan membangunan integritas aparatur pemerintahan juga dapat dilakukan melalui sebuah kebijakan kriminal (criminal policy). Upaya atau kebijakan untuk melakukan pencegahan dan penanggulangan kejahatan termasuk "kebijakan kriminal" 
(criminal policy) . kebijakan kriminal inipun tidak terlepas dari kebijakan yang lebih luas, yaitu kebijakan sosial, yang terdiri dari dari upaya/kebijakan untuk kesejahteraan sosial, dan kebijakan untuk perlindungan sosial. Dengan demikian sekiranya penanggulangan kejahatan (politik kriminal) dilakukan dengan menggunakan sarana penal (hukuman) maka kebijakan hukum pidana khususnya dalam kebijakan yudikatif harus memperhatikan dan mengarah pada tercapainya tujuan dan kebijakan sosial itu berupa social welfare dan social defence (H. Moh. Hatta, 2010 : 37-38).

Barda Nawawi Arief dalam Hibnu Nugroho menjelaskan bahwa kebijakan Hukum Pidana atau yang disebut juga sebagai politik hukum pidana mengandung pengertian tentang bagaimana mengusahakan atau membuat dan merumuskan suatu perundang-undangan yang baik (Hibnu Nugroho; 2012 : 23). kebijakan penanggulangan kejahatan merupakan bagian dari kebijakan penegakan hukum yang harus menjadi satu pedoman bagi aparat penegak hukum dalam penanggulangan kejahatan (Hibnu Nugroho; 2012 : 23).

Kebijakan Kriminal merupakan bagian dari kebijakan penegakan hukum (law enforcement policy) yang mencakup kebijakan hukum pidana, hukum perdata, dan hukum administratif, yang secara keseluruhan merupakan bagian dari politik sosial (social policy) yang merupakan usaha dari suatu masyarakat untuk meningkatkan ketahanan sosialnya yang meliputi kesejahteraan dan keamanan warganya (Muladi, Diah Sulistyani; 2016 : 154).

Kebijakan kriminal tidak membicarakan hukum secara hitam putih tetapi lebih bersifat kontekstual, artinya seberapa jauhkah hukum melindungi kepentingan-kepentingan hukum, apakah tujuan ditegakkannya hukum untuk mencapai kepastian hukum atau guna mewujudkan keadila harus dijawab secara tegas. Bagi kebijakan kriminal peraturan perundangundangan secara in abstracto harus memberi perlindungan hukum yang menyeluruh, sedangkan pada ranah penegakan hukum keadilan harus diwujudkan secara in concreto (M. Zaidan Ali; 2016 : 265-266).

Sudarto sebagaimana dikutip oleh Muladi dan Barda Nawawi Arief mengemukakan bahwa apabila hukum pidana hendak digunakan hendaknya dilihat dalam hubungan keseluruhan politik kriminil atau social 
defence planning yang inipun harus merupakan bagian integral dari rencana pembangunan nasional. Politik kriminil ialah pengaturan atau penyusunan secara rasional usaha-usaha pengendalian kejahatan oleh masyarakat (Muladi, Barda Nawawi Arief, 2016 : 157).

Tujuan akhir dari kebijakan kriminil ialah perlindungan masyarakat untuk mencapai tujuan utama yang sering disebut dengan berbagai istilah, misalnya "kebahagiaan warga masyarakat/penduduk" , "kehidupan kultural yang sehat dan menyegarkan", "Kesejahteraan masyarakat", atau untuk mencapai "keseimbangan", dengan memperhatikan tujuan-tujuan tersebut maka wajarlah apabila dikatakan bahwa politik kriminal merupakan bagian integral dari rencana pembangunan nasional (Muladi, Barda Nawawi Arief; 2016 : 158).

Penanggulangan kejahatan degan menggunakan hukum pidana merupakan cara yang paling tua setua peradaban manusia itu sendiri (Muladi, Barda Nawawi Arief; 2016 : 149), dilihat sebagai sutau masalah kebijakan maka ada yang mempermasalahkan apakah perlu kejahatan itu ditanggulangi, dicegah atau dikendalikan, dengan menggunakan sanksi pidana (Muladi, Barda Nawawi Arief; 2016 : 149).

Kebijakan penegakan hukum pidana memang selalu menjadi bagan dari kebijakan penanggulangan kriminal dalam rangka kebijakan perlindungan sosial, juga menjadi bagian yang integral dari kebijakan sosial unutk mencapai kesejahteraan masyarakat dalam menyelesaikan masalahmasalah sosial, karenanya dapat dikatakan bahwa penegakan hukum memerlukan organisasi pelaksanaan yang terdiri dari penegak hukum , perangkat peraturan perundang-undanga yang unsur-unsurnya terdiri dari aparat penegak hukum dan aparat pemerintah lainnya $(H$. Moh. Hatta, $2016: 11)$.

Mahfud MD sebagaimana dalam (Teguh Prasetyo, Abdul Halim Barkatullah, 2005 : 11-12) menjelaskan bahwa Hukum merupakan produk politik, hukum dipandang sebagai dependent variable (Variabel terpengaruh), dan politik sebagai independent variable (variable berpengaruh), dengan asumsi demikian itu Mahfud MD merumuskan politik Hukum sebagai : 
kebijakan hukum yang akan atau telah dilaksanakan secara nasional oleh pemerintah ; mencakup pula pengertian tentang bagaimana politik mempengaruhi hukum dengan cara melihat konfigurasi kekuatan yang ada dibelakang pembuatan dan penegakan hukum itu. disini hukum tidak dapat hanya dipandang sebagai pasal-pasal yang bersifat imperatif atau keharusan-keharusan, melainkan harus dipandang sebagai subsistem yang dalam kenyataanbukan tidak mungkin sangat ditentukan oleh politik baik dalam perumusan maupun impementasi dan penegakannya.

Menurut Barda Nawawi Arief dalam Teguh Prasetyo dan Abdul Halim Barkatullah bahwa kebijakan penanggulangan kejahatan dengan hukum pidana pada hakikatnya merupakan bagian dari kebijakan penanggulangan kejahatan lewat pembuatan peraturan perundang-undangan pidana yang merupakan bagian integral dari politik sosial, dan politik sosial itu dapat diartikan sebagai segala usaha rasional untuk mencapai kesejahteraan masyarakat dan sekaligus perlindungan masyarakat. dengan demikian, jika politik kriminil menggunakan politik hukum pidana maka ia harus merupakan langkah-langkah yang dibuat dengan sengaja dan sadar, memilih dan menetapkan hukum pidana sebagai sarana menanggulangi kejahatan harus benar-benar memperhitungkan semua faktor yang dapat mendukung berfungsinya atau bekerjnya hukum pidana dalam kenyataannya (Teguh Prasetyo, Abdul Halim Barkatullah; 2005 : 19).

\section{Azas Dan Teori Hukum Pembuktian}

Menurut (Andi Hamzah; 2016 : 250-257), mencari kebenaran materiil tidaklah mudah, dan dalam menilai kekuataan pembuktian alat-alat bukti yang ada dikenal beberapa sistem atau teori pembuktian, setidaknya ada 4 (empat) sistem atau teori pembuktian :

1. Sistem Atau Teori Pembuktian Berdasarkan Undang-Undang Secara Positif (Positive Wettelijk Bewijstheorie) adalah pembuktian yang didasarkan melulu kepada alat-alat pembuktian yang disebut undangundang secara positif, dikatakan secara positif karena hanya didasarkan kepada undang-undang melulu.

2. Sistem Atau Teori Pembuktian Berdasarkan berdasarkan keyakinan hakim melulu, teori ini disebut juga conviction intime. Teori ini mendasarkan pembuktian yang didasarkan pada keyakinan hati nurani hakim, sistem ini memberi kebebasan hakim terlalu besar. 
3. Sistem Atau Teori Pembuktian Berdasarkan berdasar keyakinan hakim atas alasan yang logis (Laconviction Raisonnee) menurut teori ini, hakim dapat memutus seseorang bersaah berdasarkan keyakinannya , keyakinan yang didasarkan kepada dasar-dasar pembuktian yang disertai kesimpulan yang berlandaskan kepada peraturan pembuktian tertentu. jadi putusan hakim dijatuhkan dengan suatu motivasi.

4. Sistem Atau Teori Pembuktian Berdasarkan undang-undang secara negatif (Negatief Wettelijk) dalam sistem atau teori pembuktian ini, pemidanaan didasarkan kepada pembuktian berganda, yaitu pada peraturan perundang-undangan dan pada keyakinan hakim.

Eddy O.S. Hiariej mendefinisikan hukum pembuktian sebagai ketentuan-ketentuan mengenai pembuktian yang meliputi alat bukti, barang bukti, cara mengumpulkan dan memperoleh barang bukti sampai pada penyampaian barang bukti di pengadilan serta kekuatan pembuktian dan beban pembuktian (Eddy O.S Hiariej; 2012 : 5).

Selanjutnya masih menurut Eddy O.S. Hiariej dalam kontek hukum pembuktian di Indonesia, masing-masing lapangan hukum memiliki hukum pembuktian sendiri, ada hukum pembuktian pidana dan ada hukum pembuktian perdata, bahkan seiring perkembangan berbagai kejahatan, hukum pembuktian pidana memiliki berbagai macam hukum pembuktian tergantung pada kejahatan yang dihadapi, tindak pidana umum yang ada dalam KUHP pembuktiannya mengikuti apa yang terdapat dalam KUHAP, sedangkan tindak pidana Khusus, masing-masing memiliki hukum pembuktian tersendiri seperti tindak pidana korupsi (Eddy O.S Hiariej; 2012 : 15).

Martiman Prodjohamidjojo memberikan pengertian tentang sistem pembuktian yakni sebagai suatu keseluruhan dari unsur-unsur hukum pembuktian yang berkaitan dan berhubungan dengan satu dengan yang lain serta saling pengaruh mempengaruhi dalam suatu keseluruhan atau kebulatan (Martiman Prodjohamidjojo; 2009 : 77).

Dalam pembuktian perkara pidana pada umumnya dan khususnya delik korupsi diterapkan KUHAP, sedangkan dalam pemeriksaan Delik Korupsi selain diterapkan KUHAP diterapkan juga sebagian Hukum Acara Pidana yaitu pada Bab IV terdiri atas pasal 25 sampai dengan pasal $40 \mathrm{UU}$ No 31 tahun 1999. 
Dalam Penjelasan atas undang-undang Nomor : 31 Tahun 1999 dikatakan pengertian "pembuktian terbalik yang bersifat terbatas dan berimbang" yakni terdakwa mempunyai hak untuk membuktikan bahwa ia tidak melakukan tindak pidana korupsi dan wajib memberikan keterangan tentang seluruh harta bendanya dan harta benda istri atau suami, anak, dan harta benda setiap orang atau korporasi yang diduga mempunyai hubungan dengan perkara yang bersangkutan dan penuntut umum tetap berkewajiban untuk membuktikan dakwaannya (Martiman Prodjohamidjojo; 2001 : 87).

Berkenaan dengan konteks pembuktian terbalik ini A Djoko Sumaryanto mengemukakan, bahwa terdakwa berperan aktif menyatakan bahwa dirinya bukan pelaku tindak pidana. oleh karena itu terdakwalah di depan sidang akan menyiapkan segala beban pembuktian dan bila tidak dapat membuktikan maka terdakwa dinyatan bersalah melakukan tindak pidana, dan pada hakikatnya pembalikan beban pembuktian ini merupakan penyimpangan hukum pembuktian dan juga merupakan suatu tindakan yang luar biasa terhadap tindak pidana korupsi (A. Djoko Sumaryanto; 2009 : 143).

Pendapat lain mengenai pembuktian terbalik diungkapkan oleh Indriyanto Seno Adji, yang menurutnya beban pembuktian terbalik merupakan suatu sistem pembuktian yang berada diluar kelaziman teoritis pembuktian dalam hukum acara pidana yang Universal. sebab dalam hukum pidana Formil , baik sistem kontinental maupun sistem anglo saxon hanya mengenal pembuktian dengan tetap membebankan kewajibannya kepada jaksa penuntut umum (Indriyanto Seno Adji; 2012 : 24).

Sistem pembuktian terbalik, merupakan sistem pembuktian yang dipergunakan bagi negara-negara anglo saxon dan bertujuan untuk mempermudah pembuktian dalam istilah mereka "certain cases" atau kasuskasus tertentu yang khusus sifatnya, dengan demikian beban pembuktian ini sangat terbatas pada kasus-kasus tertentu yang sangat sulit pembuktiannya, sehingga ditempuhlah suatu sistem yang sebenarnya bertentangan dengan prinsip atau asas universal mengenai pembuktian (Indriyanto Seno Adji; 2012 : 29).

Mengenai sistem pembuktian terbalik Jeremy Pope berpendapat, ungkapan "membalikkan kewajiban membuktikan" harus dihindari sedapat 
mungkin, karena istilah "membalikkan kewajiban membuktikan" itu menyesatkan dan tidak memuaskan, sehingga harus mencari istilah yang lebih tepat untuk aspek hukum ini merupakan tantangan bagi para pejuang pembaharuan hukum, dan rumusan yang lebih baik adalah "terdakwa harus memberikan penjelasan yang meyakinkan" (Jeremy Pope; 2007 : 500-501).

Aris S. Gultom seperti yang dikutip oleh Hibnu Nugroho memberikan pandangan bahwa Penerapan pembuktian terbalik dalam sistem perundangundangan Indonesia tidak dapat serta merta di justifikasi sebagai bentuk intervensi hukum terhadap hak dasar individu atau bentuk pelanggaran terhadap International Covenant on Civil and Political Right, apalagi dikaitkan dengan prinsip presumption of innocence (Hibnu Nugroho; 2015 : 18).

Tujuan penerapan pembuktian terbalik bukan untuk mengurangi isi dan ketentuan Undang-Undang yang menguasainya, tetapi ia ada dan berdiri diatas kepentingan negara dan hukum yang bertindak atas kepentingan dan harapan bangsa, menuntut pertanggung jawaban dari aparatur atas kewenangan yang ada padanya, membuktikan bahwa ia telah melaksanakan tugas dan tanggung jawan sesuai dengan ketentuan hukum, jadi yang dibuktikan secara terbalik bukan apa yang didakwakan tetapi kewenangan yang melekat padanya, besumber dari negara serta melaksanakan sesuai dengan ketentuan Undang-Undang. Untuk itu hak dasar seseorang yang dijamin pelaksanaannya dalam asas non self incrimination tidak dapat ditafsirkan secara sepihak, tetapi harus dilihat dari sudut yang lebih luas (Hibnu Nugroho; 2015 : 19).

Dalam konteks tertentu atau secara kasuistis dilihat dari kewenangan yang melekat pada individu bersangkutan hak dan kewajibannya sebagai pelaksana kepentingan bangsa dan negara berkewajiban menjamin kewenangan yang ada padanya dilaksanakan sesuai dengan ketentuan hukum yang berlaku, dengan demikian penerapan asas non self incrimination dalam pengertian terbatas juga mengandung hak dan kewajiban hukum didalamnya, sesuai dengan fungsi hukum yang memberikan pembatasan. penerapan pembuktian terbalik pada sistem perundang-undangan Indonesia tidak dapat dijustifikasi secara sempit bertentangan dengan asas non self incrimination dan keterkaitannya 
dengaan asas praduga tak bersalah, sebab penerapan asas pembuktian terbalik tidak ditujukan atas person yang bersangkutan, tetapi lebih pada pertanggung jawaban atas kewenangan yang diberikan negara kepadanya (Hibnu Nugroho, 2015 : 19).

\section{PEMBAHASAN}

Pembuktian sangat penting dalam proses pemeriksaan di pengadilan terutama untuk meyakinkan hakin sebelum menjatuhkan putusan, hal ini sesuai dengan azas yang dianut dalam Hukum Acara Pidana yaitu Azas Praduga Tak Bersalah yang bertujuan untuk melindugi terdakwa dari hukuman yang tidak sesuai dengan kesalahannya, sehingga apabila terdakwa dinyatakan bersalah harus berdasarkan pada alat bukti yang sah sehingga dapat meyakinkan hakim bahwa terdakwa bersalah telah melanggar ketentuan pidana sebagaimana yang didakwakan dalam surat dakwaan Jaksa Penuntut Umum.

Pembuktian digunakan untuk membuktikan suatu dalil yang dikemukakan dalam suatu perkara yang diajukan ke muka sidang, apabila berdasarkan pembuktian bahwa terdawa telah melakukan tindak pidana korupsi sebagaimana dinyatakan dalam surat dakwaan, maka terdakwa dijatuhi pidana, akan tetapi sebaliknya apabila dalam pembuktian yang diajukan oleh Jaksa Penuntut Umum tidak cukup untuk membuktikan kesalahan terdakwa, maka hakim harus membebaskan terdakwa.

Di sidang pengadilan, hakim harus melakukan pemeriksaan apakah unsur-unsur dari perbuatan tersebut seperti yang dinyatakan dalam surat dakwaan dalam surat tuduhan itu dapat dibuktikan atau tidak (A. Karim Nasution; 1981:199). Dalam Keputusan menteri kehakiman Republik Indonesia No : M.01.PW-07-03 tahun 1982 tentang pedoman pelaksanaan undangundang hukum acara pidana, menyatakan :

Tujuan dari Hukum acara pidana adalah untuk mencari dan mendapatkan setidak-tidaknya mendekati kebenaran materiil, ialah kebenaraanyang selengkap-lengkapnya dari suatu perkara pidana dengan menerapkan ketentuan hukum acara pidana secara jujur dan tepat bertujuan untuk mencari siapakah pelaku yang tepat yang dapat didakwakan melakukan pelanggaran hukum dan selanjutnya meminta pelaksanaan dari pengadilan guna menentukan apakah orang yang didakwakan itu dapat dipersalahkan. 
Pembuktian merupakan titik sentral pemeriksaan perkara dalam sidang pengadilan, pembuktian adalah ketentuan-ketentuan yang berisi penggarisan dan pedoman tentang cara-cara yang dibenarkan undang-undang membuktikan kesalahan yang didakwakan kepada terdakwa. Pembuktian juga mengatur alatalat bukti yang dibenarkan undang-undang yang boleh digunakan hakim untuk membuktikan kesalahan yang didakwakan (M. Yahya Harahap, 2000 : 252).

Dalam Penjelasan atas undang-undang No 31 tahun 1999 dikatakan pengertian "pembuktian terbalik yang bersifat terbatas dan berimbang" yakni terdakwa mempunyai hak untuk membuktikan bahwa ia tidak melakukan tindak pidana korupsi dan wajib memberikan keterangan tentang seluruh harta bendanya dan harta benda istri atau suami, anak, dan harta benda setiap orang atau korporasi yang diduga mempunyai hubungan dengan perkara yang bersangkutan dan penuntut umum tetap berkewajiban untuk membuktikan dakwaannya (Martiman Prodjohamidjojo; 2001 : 87).

Sistem pembuktian terbalik, merupakan sistem pembuktian yang dipergunakan bagi negara-negara anglo saxon dan bertujuan untuk mempermudah pembuktian dalam istilah mereka "certain cases" atau kasuskasus tertentu yang khusus sifatnya, dengan demikian beban pembuktian ini sangat terbatas pada kasus-kasus tertentu yang sangat sulit pembuktiannya, sehingga ditempuhlah suatu sistem yang sebenarnya bertentangan dengan prinsip atau asas universal mengenai pembuktian (Indriyanto Seno Adji; 2012 : 29).

Berdasarkan hasil wawancara dengan Narasumber perwakilan Jaksa Penuntut Umum (JPU) dari Kejaksaan Negeri Kota Banjar Ikhsan Nasrulloh, S.H. bahwa meski telah beberapa kali menangangi kasus tindak pidana korupsi yang terjadi di wilayah yurisdiksi Kejaksaan Negeri Kota Banjar namun Pihaknya belum pernah menerapkan atau menggunakan Pembuktian terbalik meskipun dalam Undang-Undang Nomor 31 Tahun 1999 jo Undang-undang No. 20 Tahun 2001 tentang pemberantasan tindak pidana korupsi telah memberikan isyarat khusus tentang pembuktian terbalik ini, belum pernah digunakannya pembuktian terbalik oleh JPU baik dari Kejaksaan Negeri Kota Banjar dan Kejaksaan Negeri Ciamis ini disebabkan oleh beberapa Hal diantaranya karena belum adanya keseragaman dalam penerapannya di samping jenis kasus korupsinya yang mudah pembuktiannya, dan faktor resiko 
penerapan asas pembuktian terbalik ini, karena apabila tidak cermat dalam menerapkan asas ini justru bisa membebaskan terdakwa bila terdakwa bisa membuktikan hartanya bukan hari hasil tindak pidana korupsi.

Sebenarnya pengadopsian asas pembuktian terbalik dalam UndangUndang nomor 31 tahun 1999 Jo Undang-undang Nomor 20 Tahun 2001 tidak lepa dari upaya untuk dapat mempermudah, mempercepat pengembalian aset hasil tindak pidana korupsi, disamping itu dapat membantu penuntut umum dalam menentukan asal-usul aset dari terdakwa. Hal ini sangat penting dilakukan karena tindak pidana korupsi masuk dalam katagori extra ordinary crime yang berdampak luar biasa bagi pembangunan, perekonomian, dan kehidupan masyarakat suatu bangsa, sehingga perlunya tindakan extra ordinary dalam penanggulangan tindak pidana korupsi (Hibnu Nugroho, 2015 : 40).

Delik korupsi adalah sebagaimana juga delik pidana pada umumnya dilakukan dengan berbagai modus operandi penyimpangan keuangan negara atau perekonomian negara, yang semakin canggih dan rumit. Sehingga banyak perkara-perkara/delik korupsi lolos dari "jaringan" pembuktian sistem KUHAP.

Upaya pembentuk undang-undang ini tidak tanggung-tanggung, karena baik dalam delik korupsi diterapkan dua sistem sekaligus, yakni sistem Undangundang No. 31 Tahun 1999 jo Undang-undang No. 20 Tahun 2001 dan sekaligus dengan sistem KUHAP. Kedua teori itu ialah penerapan hukum pembuktian dilakukan dengan cara menerapkan pembuktian terbalik yang bersifat terbatas atau berimbang, dan yang menggunakan sistem pembuktian negatif menurut undang-undang (negatief wettelijk overtuiging). Jadi, tidak menerapkan teori pembuktian terbalik murni, (zuivere omskeering bewijstlast), tetapi teori pembuktian terbalik terbatas dan berimbang.

Dimensi beban pembuktian hendaknya dilakukan secara hati-hati dan selektif karena sangat rawan terhadap pelanggaran HAM dan dilakukan dalam rangka proceeding (dalam kedudukan sebagai terdakwa), hanya karena tidak dapat membuktikan asal usul kekayaannya. Dengan demikian sekalipun dalam hal ini berlaku asas praduga bersalah (presumption guilt) dalam hal presumption of corruption, tetapi beban pembuktian terbalik tersebut harus dalam kerangka proceeding kasus atau tindak pidana tertentu yang sedang diadili berdasarkan undang-undang. 
Dalam perkembangan hukum dewasa ini peningkatan kesadaran hukum masyarakat semakin meningkat, dengan peningkatan kesadaran masayarakat akan hak-hak mereka juga semakin menjadi tuntutan yang tidak bisa dengan begitu saja diabaikan, peningkatan kesadaran masyarakat ini juga mempengaruhi persepsi masyarakat terhadap asas pembuktian terbalik (Hibnu Nugroho, 2015 : 40). Wahyu Wiriadinata sebagaimana di kutip oleh Hibnu Nugroho memberikan pandangan, dari pendekatan doktrin dan komparasi sistem hukum pidana (termasuk UU No 31 tahun 1999 pasal 37 beserta penjelasannya), makna atau arti "terbatas" atau "khusus" dari implementasi sistem pembalikan beban pembuktian adalah (Hibnu Nugroho; 2015 : 40-42) :

1. Sistem pembalikan beban pembuktian hanya terbatas dilakukan terhadap tindak pidana "gratification" (pemberian) yang beraitan dengan "bribery" (suap) dan buan terhadap delik-delik lainnya dalam tindak pidana korupsi.

2. Delik-delik lainnya dalam undang-undang No 31 tahun 1999 yang tertuang dalam pasal 2 sampai pasal 16 beban pembuktiannya tetap ada pada jaksa penuntut umum.

3. sistem pembalikan beban pembuktian hanya terbatas dilakukan terhadap "perampasan" dari delik-delik yang didakwakan terhadap siapa saja sebagaimana tertuang daam pasal 2 sampai pasal 16 undang-undang no 31 tahun 1999. Perlu ditegaskan pula bahwa sistem pembuktian terhadap dugaan pelanggaran pada pasal 2 sampai dengan pasal 16 undang-undang no 31 tahun 1999 tetap diberikan pada jaksa penuntut umum. apabila terdakwa berdasarkan tuntutan jaksa penuntut umum dinilai terbukti melakukan pelanggaran salah satu dari tindak pidana tersebut dan dikenakan perampasan terhadap harta bendanya, terdakwa wajib membuktikan bahwa harta bendanya bukan berasal dari tindak pidana korupsi.

4. bahwa setiap pembalikan beban pembuktian terbatas penerapan asas Lex Temporis-nya yakni sistem ini tidak dapat diberlakukan secara retro aktif (berlaku surut) karena potensial terjadinya pelanggaran HAM, pelanggaran terhadap asas legalitas, dan menimbulkan apa yang dinamakan asas Lex Talionis (balas dendam)

5. Bahwa sistem pembalikan beban pembuktian terbatas dan tidak diperkenankan menyimpang dari asas "Daad - daderstrafrecht" 
6. Dari pengertian ini, sistem pembalikan beban pembuktian sangat tidak diperkenankan melanggar hak-hak prinsipiel dari pembuat/pelaku (tersangka/terdakwa), bahwa penerapan pembalikan beban pembuktian ini sebagai kenyataan yang tidak dapat dihindari , khususnya terjadinya minimalisasi hak-hak dari "dader" yang berkaitan dengan asas "non self incrimination" dan praduga tak bersalah, namun demikian adanya suatu minimalisasi hak-hak tersebut sangat dihindari akan terjadinya eliminasi hak-hak tersebut, dan apabila terjadi inilah yang dikatakan bahwa sistem pembalikan beban pembuktian adalah potensial terjadinya pelanggaran HAM.

Selama ini asas pembuktian terbalik selau dilawankan dengan asas praduga tak bersalah, namun dengan melihat bagaimana penerapan asas pembuktian terbalik serta nilai filosofis asas tersebut maka paradigma tersebut sudah seharusnya dikesampingkan, disamping itu adanya sikap berlebihlebihan dalam menafsirkan asas praduga tak bersalah sudah waktunya dikesampingkan. Mien Rukmini sebagaimana di kutip oleh Hibnu Nugroho memberikan pandangan beberapa tolok ukur pengukuran dalam penafsiran penerapan asas praduga tak bersalah adalah sebagai berikut (Hibnu Nugroho; $2015: 42-43)$ :

1. perlindungan terhadap sewenang-wenang dari pejabat negara termasuk didalamnya kepolisian, kejaksaan, komisi khusus yang diberikan wewenang untuk melakukan pengusutan terhadap kejahatan tertentu misalnya KPK dan pihak pengadilan termasuk hakim.

2. bahwa pengadilanlah yang berhak menentukan salah tidaknya terdakwa.

3. bahwa sidang pengadilan harus terbuka untuk umum (tidak boleh bersifat rahasia); dan

4. bahwa tersangka / terdakwa harus diberikan jaminan-jaminan untuk dapat membela diri sepenuhnya.

Oleh sebab itu apabila hak-hak tersebut telah dapat dilaksanakan maka berarti sudah tidak ada lagi pelanggaran terhadap asas praduga tak bersalah, apalagi bila dihubungkan dengan kejahatan luar biasa seperti tindak pidana korupsi maka keraguan sikap dengan berlindung dibalik asas praduga tak bersalah yang sebenarnya telah ditafsirkan secara berlebihan justru akan 
merugikan amanat penegakan hukum yang diberikan oleh undang-undang (Hibnu Nugroho; 2015 : 43).

Berangkat dari hal-hal tersebut diatas maka penerapan asas pembuktian terbalik sebagaimana diatur dalam undang-undang nomor 31 tahun 1999 Jo Undang-undang Nomor 20 Tahun 2001 tentang pemberantasan tindak pidana korupsi tidak perlu diragukan lagi, asas ini seharusnya dapat dimanfaatkan secara maksimal oleh penuntut umum dalam menangani kasus-kasus korupsi.

Berdasarkan hasil wawancara dengan narasumber dari Jaksa Penuntut umum Kejaksaan Negeri Kota Banjar yakni Ikhsan Nasrulloh, S.H., dan kepala seksi tindak pidana khusus Kejaksaan Negeri Ciamis Faetony Yosy Abdullah, S.H., bahwa penanganan kasus tindak pidana korupsi yang selama ini dilaksanakan belum pernah menggunakan pembuktian terbalik, hal ini dikarenakan ada beberapa kendala diantaranya belum adanya ketentuan khusus yang mengatur tentang pembuktian terbalik itu selain itu juga karena belum adanya instruksi khusus atau kebijakan dari internal kejaksaan mengenai penerapan pembuktian terbalik khusus untuk kasus korupsi. berikut ini penjelasan dari kepala seksi tindak pidana khusus Kejaksaan Negeri Ciamis

\section{Faetony Yosy Abdullah, S.H. :}

penerapan pembuktian terbalik masih sulit untuk dilakukan hal ini dikarenakan substansi dalam sistem hukum di Indonesia belum mengatur secara tegas tentang penerapan pembuktian terbalik ini sehingga perlu diadakan perubahan terhadap Undang-undang Nomor 20 Tahun 2001 tentang Tindak Pidana Korupsi agar penerapan dari pembuktian terbalik ini dapat dilakukan secara tegas. Hal ini menunjukkan bahwa pembuktian terbalik belum diterapkan secara efektif dalam prakteknya sehingga perlu diadakan perubahan terhadap undangundang yang mengatur tentang hal ini. Sehingga nantinya pembalikan beban pembuktian ini bisa membantu dalam mengungkap kasus tindak pidana korupsi.

Selain itu bahwa Usulan dari narasumber kepala seksi tindak pidana khusus Kejaksaan Negeri Ciamis Faetony Yosy Abdullah, S.H. agar diadakan perubahan terhadap Undang-undang No. 20 Tahun 2001 tentang Tindak Pidana Korupsi agar penerapan dari pembuktian terbalik ini dapat dilakukan secara tegas ini juga sesuai terori yang disampaikan oleh Barda Nawawi Arief sebagaimana di kutip oleh Hibnu Nugroho yang menjelaskan bahwa kebijakan Hukum Pidana atau yang disebut juga sebagai politik hukum pidana mengandung pengertian tentang bagaimana mengusahakan atau membuat dan 
merumuskan suatu perundang-undangan yang baik (Hibnu Nugroho; 2012 : 23) kebijakan penanggulangan kejahatan merupakan bagian dari kebijakan penegakan hukum yang harus menjadi satu pedoman bagi aparat penegak hukum dalam penanggulangan kejahatan (Hibnu Nugroho; 2012 : 23).

\section{SIMPULAN DAN SARAN}

\subsection{Simpulan}

Dari hasil penelitian yang telah dilakukan dapat ditarik simpulan sebagai berikut :

1. Bahwa Pembuktian terbalik dalam penanganan kasus tindak pidana korupsi yang ditangani oleh Kejaksaan Negeri Ciamis dan Kejaksaan Negeri Kota Banjar belum pernah atau belum digunakan oleh jaksa penuntut umum, hal ini terjadi dikarenakan belum ada peraturan perundang-undangan yang spesifik mengatur secara tegas tentang penerapan pembuktian terbalik

2. Kendala kendala dalam penerapan kebijakan pembuktian terbalik adalah pembuktian terbalik tersebut yakni kebanyakan harta kekayaan yang dimiliki oleh pelaku tindak pidana korupsi bukan atas nama dari pelaku korupsi tersebut atau dengan kata lain para pelaku korupsi tersebut melakukan pencucian uang guna menyamarkan harta kekayaan dari hasil tindak pidana korupsi, sehingga akan sulit jika harus diadakan pembuktian terbalik.

\subsection{Saran}

1. Kebijakan formulasi pembuktian tebalik dalam Undang-Undang Tindak Pidana Korupsi yang menganut sistem pembuktian terbalik secara terbatas sudah seharusnya diubah menjadi pembuktian terbalik secara murni seperti yang diatur dalam Rancangan Undang-Undang Tindak Pidana Korupsi, agar pembuktian terbalik dapat segera diterapkan dalam kasus tindak pidana korupsi, sehingga tidak timbul keraguan dalam penerapannya.

2. Dalam perumusan perubahan atas Undang-undang No. 20 Tahun 2001 tentang Tindak Pidana Korupsi supaya aturannya tepat sasaran dan tidak terpengaruh oleh banyaknya kepentingan politik dan juga hendaknya memperhatikan asas hukum umum dan asas hukum 
khusus sehigga mempunyai spirit yang sama antara penegak hukum dengan masyarakat dan tidak menimbulkan penafsiran diantara para penegak hukum.

\section{DAFTAR PUSTAKA}

Adji, Indriyanto Seno, 2012, Korupsi Dan Permasalahannya, Diadit Media Press, Jakarta.

Ali, H Faried dan H Andi Syamsu Alam, 2012, Studi Kebijakan Pemerintah, Refika Aditama, Bandung.

Ali , M. Zaidan, 2016, Kebijakan Kriminal, Sinar Grafika, Jakarta.

Atmasasmita, Romli, 2002, Korupsi, Good Governance dan Komisi Anti Korupsi di Indonesia, Badan Pembinaan Hukum Nasional Departemen Kehakiman dan HAM RI, Jakarta.

Hamzah, Andi, 2016, Hukum Acara Pidana Indonesia (edisi kedua), Sinar Grafika, Jakarta.

Harahap, M. Yahya, 2000, Pembahasan, Permasalahan Dan Penerapan KUHP Jilid 2, Sinar Grafika.

Hatta, H. Moh, 2010, Kebijakan Politik Kriminal (penegakan hukum dalam rangka penanggulangan kejahatan), Pustaka Pelajar, Yogyakarta.

Hiariej, Eddy O.S, 2012, Teori Dan Hukum Pembuktian, Penerbit Erlangga, Jakarta.

Klitgaard, Robert, 2005, Penuntun Pemberatasan Korupsi Dalam Pemerintahan Daerah, Yayasan Obor Indonesia.

Muladi dan Barda Nawawi Arief, 2010, Teori-Teori dan Kebijakan Pidana, PT. Alumni, Bandung.

Muladi dan Diah Sulistyani, 2016, Kompleksitas Perkembangan Tindak Pidana dan Kebijakan Kriminal, PT. Alumni, Bandung.

Mulyadi, Lilik, 2007, Tindak Pidana Korupsi Di Indonesia, Normatif, Teoritis, Praktik dan Masalahnya, PT. Alumni, Bandung.

2013, Pembalikan Beban Pembuktian Tindak Pidana Korupsi, PT. Alumni, Bandung.

Nasution, A. Karim, 1981, Masalah Surat Tuduhan Dalam Proses Pidana, CV Pandjuran Tujuh, Jakarta.

Nugroho, Hibnu, 2012, Integralisasi Penyidikan Tindak Pidana Korupsi di Indonesia, Media Prima Aksara, Jakarta. 
2013, Efektivitas Fungsi Koordinasi dan Supervisi dalam penyidikan tindak Pidana Korupsi oleh Komisi Pemberantasan Korupsi, Jurnal Dinamika Unsoed Vol 13 No 3, September 2013.

2015, Penerapan Asas Pembuktian Terbalik Dalam Tindak Pidana Korupsi di Kejaksaan Tinggi Jawa Tengah (Laporan Tahunan Fasilitasi Guru Besar) , Unsoed.

2016, Optimalisasi Pencegahan Tindak Pidana Korupsi di Indonesia (sebuah tinjauan singkat), Saraswati Nitisara, Semarang.

Nugroho, Riant, 2014, Public Policy : Teori, Manajemen, Dinamika, Analisis, Konvergensi, Dan Kimia Kebijakan, Elex Media Komputindo, Jakarta.

Poernomo, Bambang, 1993, Pokok-Pokok Tata Aacara Peradilan Pidana Indonesia, dalam Undang-Undang RI no 8 Tahun 1981, Liberty , Yogyakarta..

Pope, Jeremy, 2007, Strategi Memberantas Korupsi Elemen Sistem Intigritas Nasional, Yayasan Obor Indonesia, Jakarta.

Pramono, R Widyo, 2016, Pemberantasan Korupsi Dan Pidana Lainnya Sebuah Perspektif Jaksa Dan Guru Besar, Penerbit Buku Kompas.

Prasetyo, Teguh Abdul Halim Barkatullah, 2005, Kajian Kebijakan Kriminalisasi dan Dekriminalisasi, Pustaka Pelajar, Yogyakarta.

Prodjohamidjo, Martiman, 2001, Penerapan Pembuktian Terbalik dalam Delik Korupsi (UU No31 tahun 1999), CV. Mandar Maju, Bandung.

Said, Noor Aziz, 2011, Disertasi : Pertanggung Jawaban Pidana Dan Pertanggung Jawaban Administratif Terhadap Tindak Pidana Korupsi APBD Yang Dilakukan Oleh Anaggota DPRD, Program Doktoral Undip Semarang.

Soedirjo, 1995, Jaksa dan Hakim dalam Proses Pidana, CV Akademikia Pressindo, Jakarta.

Sujata, Antonius, 2000, Reformasi dalam Penegakan Hukum, Penerbit Djambatan, Jakarta.

Sumaryanto, A Djoko, 2009, Pembalikan Beban Pembuktian Tindak Pidana Korupsi Dalam Rangka Pengembalian Kerugian Keuangan Negara, Prestasi Pustaka Publisher, Jakarta.

Winarno, Budi, 2012, Kebijakan Publik, Teori, Proses, dan Studi Kasus, Penerbit CAPS, Yogyakarta.

2012, Teori Dan Proses Kebijakan Publik, MEDPress, Yogyakarta. 